Autismos

Paulina S. Rocha (org.)

Sāo Paulo, Escuta

1997

\title{
Sobre o jeito cepepeliano de avançar na construção de uma clínica psicanalítica
}

\author{
Maria Cristina Kupfer
}

Clínicas psicanalíticas, há muitas. As clínicas em questão não são os estabelecimentos em que se pratica a psicanálise. Fala-se aqui das muitas possibilidades, estilos, modelos e "desenhos" institucionais que podem ser reunidos sob a denominação "clínica psicanalítica".

No livro Autismos, pode-se assistir, com grande entusiasmo, ao relato da construção, bem como ao modus operandi, de uma das clínicas psicanalíticas mais expressivas de que se tem notícia no Brasil: a clínica do CPPL, uma instituição do Recife para crianças psicóticas e autistas. Uma clínica singular.

Nas palavras de Paulina Rocha, fundadora do CPPL, esse livro trata do "jeito cepepeliano de avançar na construção de uma prática clínica psicanalítica". Quem diz jeito, diz estilo. "O estilo é aquilo que se transmite", diz Lacan. E é exatamente isso que o CPPL faz em seu livro: transmite seu estilo. Mas qual é esse estilo cepepeliano?

Em primeiro lugar, veja-se o que ele não é. Nada de soluções de tipo asilar ou de análises institucionais 


\section{RESENHAS}

que tratam todas as ocorrências como neurose institucional. A infindável atitude interpretativa das ações da equipe só produz, como já se sabe, mais resistência. Ao recusar a dimensão paranóica e "paranoizante" da análise institucional, fomentadora de formações imaginárias, o CPPL já produz seu primeiro avanço.

Há outros. Um traço característico do estilo cepepeliano parece ser a sustentação de uma relação com a teoria que é livre de amarras políticoinstitucionais. Por não servir a mestres, mas por colocar em primeiro plano o compromisso ético com seus pacientes, há um constante questionamento da teoria. Paulina Rocha debate com Kanner: ao longo dos quinze anos de vida do CPPL, ela viu passar por lá uma porcentagem muito pequena do tipo de pais descrito por ele. Não concorda com Green, pois sua experiência lhe diz que é preciso mais do que um desinvestimento paterno na mãe para constituir um autista - é preciso que também tenha havido um desinvestimento do pai sobre seu filho. Pode-se, talvez, discutir com Rocha a necessidade de instituir, metapsicologicamente, uma figura paterna em sua dimensão desejante, ao lado do desejo materno; para a constituição do sujeito. Mas é inegável que esse desinvestimento feito pelo pai do autista em relação a seu filho não é de modo algum sem conseqüências. E essas constatações foram legítima e psicanaliticamente extraídas de uma laboriosa e comprometida investigação clínica que põe constantemente a teoria à prova.

Porque parte da clínica, o CPPL tem também momentos de encontro insuspeitado com teorias que seus integrantes nem sempre professam. Sabe-se que, muitas vezes, certas experiências clínicas comuns impõem-se à pena de teóricos das mais diversas filiações, ficando a variação por conta do modo de recortá-las, interpretá-las e, portanto, de intervir sobre elas. Um desses encontros insuspeitados diz respeito à formulação de uma transferência subjetal, tomada de empréstimo de Xavier Jacquey. "Na repetição que acontecia na transferência subjetal, no setting analítico, havia uma inversão em relação aos lugares que sujeito e objeto da transferência deveriam normalmente ocupar". Embora a noção de sujeito encontre diferentes inflexões nas várias teorias psicanalíticas, essa formulação acerca da troca de lugares na transferência também se encontra em Lacan. Năo por coincidência, a experiência clínica dos praticantes aponta na mesma direção indicada por Lacan e Jacquey. Sabe-se bem que a sustentação da relação com essas crianças subverte o cotidiano da clínica psicanalítica da neurose, e provoca no analista uma inquietante estranheza, já que, paradoxalmente, toda demanda dirigida ao autista é por ele vivida, lembra Jerusalinsky, como demanda de exclusão.

No desenho institucional que foi aos poucos tomando forma no CPPL, encontra-se uma das mais criativas maneiras de abordar os efeitos das psicoses 
infantis sobre os encarregados de seu tratamento. "A solução que encontramos no CPPL foi a criação de um enquadramento específico para a equipe, uma espécie de reduplicação do enquadramento clássico, por isso chamado, durante anos, de duplo enquadramento: a equipe e o coordenador da terapia intensiva passaram a ser submetidos às mesmas interdições e leis, em espaços e tempos diferentes. Foi assim que o enquadramento manteve sua função de terceiro." $\mathrm{O}$ fundamento dessa concepção é extraído diretamente de Freud, e se transformou em um manejo clínico eficiente. O funcionamento do duplo enquadramento pode ser acompanhado com clareza no texto de Ana Maria Rocha de Oliveira. Ali é possível assistir ao desdobramento e às inflexões que ocorreram no caso clínico graças ao trabalho, produzido pela equipe, no interior do duplo enquadramento. Diga-se ainda que o texto de Ana Maria possui uma leveza que torna agradável a sua leitura.

O trabalho de Antonio Ricardo Rodrigues da Silva também carrega a marca do estilo do CPPL: o recurso à mitologia, caro a Freud, aqui retorna como indicador de um discurso psicanalítico ávido do diálogo com a cultura, e que bordeja suas fronteiras em busca do encontro com outras produçōes de saber. O mito da autoctonia é invocado por Antonio Ricardo para ler a origem do autismo: uma origem autóctone porque desvinculada de qualquer filiação, o que obrigaria o autista à fundação de uma nova. Fazendo uso de uma afirmação de Lacan, segundo a qual o mito é o que dá forma épica ao que opera na estrutura, pode-se dizer, então, que a autoctonia é o fato de estrutura fundante do autismo, já que aí não há filiação. Mas um problema persiste: é pouco provável que se funde para o autista, a partir daí, algo equivalente a uma nova genealogia. O mito da autoctonia não se aplica então de forma completa à estrutura do autismo, embora ajude a lançar luzes sobre o modo de conceber seu surgimento.

Os trabalhos de Ana Elizabeth Cavalcanti e de M. Helena de Barros e Silva testemunham a vocação cepepeliana para a prática da metapsicologia, sendo nisso fiéis à tradição psicanalítica. Ana Elizabeth trata com rigor o caso clínico que relata e exemplifica com clareza o modo como se conduzem os tratamentos individuais no CPPL: os recursos são a interpretação da transferência e o trabalho com pais. Estes são escutados ao longo do tratamento e aí ocupam um lugar privilegiado, já que seus ditos perpassam toda a análise. O estilo é o psicanalítico, do que se deduz então que, para o CPPL, as análises individuais podem seguir o modelo psicanalítico clássico. Nesse sentido, os cepepelianos discordam, por exemplo, de Laznik-Penot ou de Colette Soler, para quem a análise do autista é uma "psicanálise invertida". Nessas análises, trata-se justamente - como se vê no texto de Ana Elizabeth - da construção de uma imagem corporal a ser narcisicamente investida, ao contrário da análise clássica, em que a dimensão alienante e narcísica do eu é subvertida. 


\section{RESENHAS}

Veja-se agora um outro traço do estilo do CPPL, que aparece no modo de tratar a questão diagnóstica. Segundo Paulina Rocha, o livro propõe que se abarquem as psicoses infantis e o autismo sob a denominação "autismos". Por esse motivo, os autores do livro, ao fazerem relatos clínicos, não tecem comentários diagnósticos, já que todos os pacientes são, "por convenção", autistas.

Sabemos da dificuldade que se enfrenta hoje quando se trata de afirmar diagnósticos, e estamos assistindo a uma verdadeira reordenação do campo teórico em que figuram essas patologias infantis. $\mathrm{O}$ esforço teórico da psicanálise atual vem sendo o de traçar mais nitidamente a fronteira diferencial entre o autismo e a psicose. Ao mesmo tempo, alarga-se o escopo das psicoses infantis, para fazer entrarem as patologias de origem orgânica, ou com origem no discurso social, todas elas girando em torno de um eixo: trata-se de quadros em que a posição da criança frente ao simbólico falha. Assim, colocar autismo e psicose sob a mesma rubrica é um movimento na contramão do que vem sendo discutido atualmente na psicanálise.

Finalmente, deve-se observar a pertinência da inclusão de um texto de Kanner que ainda não havia recebido uma tradução para o português. Para os praticantes da clínica do autismo, trata-se de um texto imprescindível, já que nele se pode assistir ao nascimento dessa clínica, em um relato vivo que ainda conserva sabor de atualidade. No texto de Kanner, podem-se reconhecer muitos dos traços de nossos pacientes.

De fato, clínicas psicanalíticas, há muitas. A do CPPL se afirma em seu estilo absolutamente próprio. Mas, não se pode esquecer, ali se pratica a psicanálise. Como disse Joel Birman no prefácio do livro, o CPPL parte de um pressuposto ético de que existe linguagem e um sujeito no mundo autista. É isto que o aproxima das demais clínicas psicanalíticas. Elas são muitas. A psicanálise, porém, pode ser uma só, e disso, sobretudo, o CPPL dá testemunho. 